\title{
Effects of Angular Leaf Spot and Rust on Yield Loss of Phaseolus vulgaris
}

\author{
W. C. de Jesus Junior, F. X. R. do Vale, R. R. Coelho, B. Hau, L. Zambolim, L. C. Costa, and A. Bergamin Filho
}

First, second, third, fifth, and sixth authors: Departamento de Fitopatologia, Universidade Federal de Viçosa, 36571-000 Viçosa, MG, Brazil; fourth author: Institut für Pflanzenkrankheiten und Pflanzenschutz, Universität Hannover, 30419 Hannover, Germany; and seventh author: Departamento de Entomologia, Fitopatologia e Zoologia Agrícola, ESALQ/USP, 13418-900 Piracicaba, SP, Brazil. Accepted for publication 17 July 2001.

\begin{abstract}
de Jesus Junior, W. C., do Vale, F. X. R., Coelho, R. R., Hau, B., Zambolim, L., Costa, L. C., and Bergamin Filho, A. 2001. Effects of angular leaf spot and rust on yield loss of Phaseolus vulgaris. Phytopathology 91:1045-1053.

Three field experiments were conducted in 1997, 1998, and 1999 to investigate the effects of angular leaf spot and rust, separately or combined, on host growth and yield of individual bean plants (Phaseolus vulgaris). In each experiment, three treatments were established by inoculating cv. Carioca with Phaeoisariopsis griseola, Uromyces appendiculatus, or with both pathogens. An additional control treatment was not inoculated, but was sprayed with a fungicide. In the 1997 and 1999

the highest in 1997 and lowest in 1998. In each experiment, the treatments did not differ significantly to the area under leaf area progress curve, HAD, and healthy leaf area absorption (HAA). All inoculated treatments had significantly more severe disease and less yield than the control treatment. Based on the analysis of 60 plants in each experiment, yield was not related to the areas under disease progress curve for either or both diseases. In 1997 and 1999, yield was related to HAD $\left(R^{2}=0.57\right.$ and 0.43$)$ and HAA $\left(R^{2}=0.60\right.$ and 0.55$)$. Based on the combined analysis of all 36 plots, angular leaf spot reduced the leaf area because of defoliation, whereas rust did not affect the leaf area. Rust reduced yield more than four times that of angular leaf spot, although the decrease in photosynthesis to angular leaf spot was twice that of rust.
\end{abstract} experiments, angular leaf spot reached higher disease levels than rust, whereas in 1998, rust was more severe than angular leaf spot. Host growth, expressed as healthy leaf area duration (HAD), and yield were
Additional keywords: disease interaction, disease-yield relationship.
Detailed information about crop loss is the basis for any valid economic analysis of disease-management strategies. Disease control does not increase yield but rather reduces crop loss; thus, information on the relationships between disease and control measures, and disease and yield, are indispensable to make decisions in the management of plant diseases (35). Similarly, economical crop production requires quantitative information about how diseases affect crop productivity (18).

The occurrence of two or more pathogens on the same host at the same time is frequent, especially on tropical crops $(28,36)$. Usually the effects of a disease complex on yield are estimated by assuming that each disease acts independently. However, the simultaneous occurrence of diseases can lead to combined effects on crop yield and on the population dynamics of the pathogens. In general, the interactions of pathogens complicate the control of diseases and the partitioning of the primary causes of loss. These interactions may alter the occurrence and speed of epidemics and can have significant implications to assess crop losses, diagnose the causes of these losses, select appropriate management strategies, and forecast, model, and simulate epidemics $(1,36)$. Nevertheless, only a few investigations of crop losses and population dynamics of interacting pathogens or diseases have been published (19-21,26,37).

In common beans (Phaseolus vulgaris L.), angular leaf spot (caused by Phaeoisariopsis griseola [Sacc.] Ferraris) and rust (caused by Uromyces appendiculatus [Pers.:Pers.] Unger) are the most destructive foliar diseases in Brazil. P. griseola causes lesions on leaves, pods, branches, and petioles that result in severe

Corresponding author: F. X. R. do Vale; E-mail address: dovale@mail.ufv.br

Publication no. P-2001-0829-01R

(C) 2001 The American Phytopathological Society defoliation. The symptoms of $U$. appendiculatus are chlorotic, raised pustules on the surface of leaves, pods, and petioles, without causing severe defoliation. In the absence of adequate control measures, reductions in yield to angular leaf spot of $70 \%$ in Brazil (6) and $80 \%$ in Colombia (31). Some reported losses to rust were 36 to $45 \%$ in Brazil (25) and $22 \%$ in Colombia (34).

Reliable estimates of losses caused by these two important foliar diseases are a prerequisite for the rational development of any bean protection program. Accordingly, the main objective of this study was to determine the effects of these two diseases, separately and combined, on crop growth and on loss in yield of bean plants.

\section{MATERIALS AND METHODS}

Field experiments. Three field experiments were conducted at the Universidade Federal de Viçosa, Minas Gerais State, Brazil, from October to December 1997, May to July 1998, and February to May 1999, with bean cv. Carioca. All experiments were set in a randomized complete block design with four treatments and three replications. Each plot $\left(16 \mathrm{~m}^{2}\right)$ consisted of eight $4 \mathrm{~m}$ long rows, spaced $0.5 \mathrm{~m}$ apart. There was $1 \mathrm{~m}$ between plots. To avoid cross contamination among plots with different treatments, only the four central rows of each plot were used for assessment $(0.5 \mathrm{~m}$ at the end of each row was omitted). Twelve seeds were sown, and 10 plants were allowed to grow per linear meter of row. The plots were maintained with the conventional cultural practices used in commercial fields, which included planting, topdressing with fertilizer, insecticide sprays, weeding, and, when necessary, sprinkle irrigation. The treatments were (i) inoculation with $P$. griseola; (ii) inoculation with $U$. appendiculatus; (iii) inoculation with $P$. griseola $+U$. appendiculatus; and (iv) a control treatment (not inoculated). These treatments will be referred hereafter as P, U, 
$\mathrm{P}+\mathrm{U}$, and $\mathrm{C}$, respectively. The plants were inoculated, always at nightfall, with $P$. griseola or $U$. appendiculatus with a spore suspension at a concentration of $10^{4}$ spores per $\mathrm{ml}$ for each pathogen (2 liters of spore suspension per plot). For the treatment $\mathrm{P}+\mathrm{U}$, the inoculation with each pathogen was made separately in the same plot. The first inoculation was made when the second trifoliolate leaf had expanded (approximately 30 days after planting), and the second inoculation followed 10 days later. The control plots were sprayed with tebuconazole at $0.75 \mathrm{~kg} \mathrm{ha}^{-1}$ (187.5 $\mathrm{g}$ a.i. $\mathrm{ha}^{-1}$ ) the day before each inoculation.

Crop growth, disease severity, and yield. Crop growth and disease severity were evaluated in the four central rows of each plot. The single-plant approach was adopted (20), in which five plants in each plot were marked with plastic tape, and thus, a total of 60 plants per trial was assessed weekly. The plants were marked after the appearance of the first trifoliolate leaf, and individual plants of similar height and vigor were selected.

The leaf area (LA; square centimeter) of all leaves on each marked plant was assessed weekly, starting with the appearance of the first trifoliolate leaf. The maximum width of the central leaflet of each leaf ( $W$; centimeter) was measured with a ruler and LA was estimated for each leaf from the empirical relationship (17): $\mathrm{LA}=2.1371 W^{1.9642}-2.7013$ with $R^{2}=0.95$. The sum of the leaf areas of individual leaves represented the leaf area per plant (LAP; square meter).

The visual severities of angular leaf spot $\left(X_{A}\right)$ and bean rust $\left(X_{R}\right)$ were assessed simultaneously with the leaf area measurements by using diagrammatic scales for each disease (14). The average severity (in percentage) of the three leaflets of all leaves on the marked plants was estimated. Both diseases were separately evaluated in all treatments because natural infections occurred in the field. The total disease severity $\left(X_{T}\right)$ was calculated as the sum of the two individual disease severities of $X_{A}+X_{R}$.

The concept of the virtual lesion (3) was adopted, and the virtual disease severities for rust and angular leaf spot were calculated as $X_{\beta R}=100\left[1-\left(1-0.01 X_{R}\right)^{\beta R}\right]$ and $X_{\beta A}=100\left[1-\left(1-0.01 X_{A}\right)^{\beta A}\right]$. The $\beta$ values applied here were $\beta_{R}=2$ for bean rust (2) and $\beta_{A}=4$ for angular leaf spot (2). The total virtual disease severity $\left(X_{\beta T}\right)$ was determined by employing the multiple infection transformation (15) for the individual diseases and for the overlap of lesions of the two diseases on the same leaf, which led to $X_{\beta T}=100[1-$ $\left.\left(1-0.01 X_{R}\right)^{\beta R} \times\left(1-0.01 X_{A}\right)^{\beta A}\right]$.

Defoliation was observed but not quantified. 'Carioca' has an indeterminate, polybrachiate growth habit that makes it difficult to identify specific leaves in sequential assessments. Thus, the total numbers, areas, and original positions of fallen leaves were not considered. At each evaluation, the stage of host growth was determined by the descriptive scale of Van Schoonhoven and Pastor-Corrales (33).

In the first, second, and third experiment, beans were harvested at 88,103 , and 93 days after planting, respectively. Yield $(Y)$ was determined for each marked plant (gram per plant) and per plot (gram per square meter) by weighing the seeds (with $12 \%$ moisture).

Integral variables. The area under disease progress curve (AUDPC) and the area under leaf area progress curve (AULAPC) for each plant were calculated by trapezoidal integration over the $n$ observation dates. The numbers of observations were 7,10 , and 7, respectively, for the first, second, and third trial. For each disease, the AUDPC was calculated as

$$
\mathrm{AUDPC}=\sum_{i=1}^{n-1}\left(\frac{X_{i}+X_{i+1}}{2}\right)\left(t_{i+1}-t_{i}\right)
$$

where $X$ is the disease severity (in percentage) specified by a subscript $R$ for bean rust, $A$ for angular leaf spot, and $T$ for the total of both disease severities. Similarly, the AUDPC of a specific disease is indicated by a subscript.
Accordingly, AULAPC (square meter per day) was calculated with the leaf area per plant (LAP; square meter):

$$
\mathrm{AULAPC}=\sum_{i=1}^{n-1}\left(\frac{\mathrm{LAP}_{i}+\mathrm{LAP}_{i+1}}{2}\right)\left(t_{i+1}-t_{i}\right)
$$

Under the assumption of 20 plants per $\mathrm{m}^{2}$, the leaf area index (LAI) was calculated as LAI $=20 \mathrm{LAP}$. The integration of LAI led to the leaf area index duration (LAD), which was defined as

$$
\mathrm{LAD}=\sum_{i=1}^{n-1}\left(\frac{\mathrm{LAI}_{i}+\mathrm{LAI}_{i+1}}{2}\right)\left(t_{i+1}-t_{i}\right)
$$

The healthy leaf area index (HLAI) was determined as HLAI = $\operatorname{LAI}\left(1-0.01 X_{T}\right)$. The integration of HLAI over the season resulted in healthy leaf area duration (HAD; days).

The effective leaf area index (ELAI) (30) could be calculated as ELAI $=\operatorname{LAI}\left(1-0.01 X_{\beta T}\right)$. The integration over the season resulted in the effective leaf area index duration (ELAD). This is identical to the photosynthesizing leaf area index duration (PAD) of (2)

$$
\mathrm{ELAD}=\sum_{i=1}^{n-1}\left(\frac{\mathrm{ELAI}_{i}+\mathrm{ELAI}_{i+1}}{2}\right)\left(t_{i+1}-t_{i}\right)
$$

The radiation intercepted $\left(\mathrm{RI}_{i}\right)$ (megajoule per square meter) was given by $\mathrm{RI}_{i}=I_{i}\left[1-\exp \left(-k \times \mathrm{LAI}_{i}\right)\right]$, in which $I_{i}$ was the average incident solar radiation (megajoule per square meter) in the period $\left(t_{i+1}-t_{i}\right)$ and $k$ was the extinction coefficient. According to Miglioranza (24), the $k$ value for cv. Carioca is 0.7 . The intercepted radiation of the healthy leaf area (HRI) in megajoule per square meter for each assessment was determined as HRI $=\mathrm{RI}\left(1-X_{T}\right)$. The integration over the observation time resulted in the healthy leaf area absorption (HAA), measured in megajoule per square meter as

$$
\mathrm{HAA}=\sum_{i=1}^{n-1}\left(\frac{\left(1-X_{i}\right)\left(1-e^{\left(-k \mathrm{LAI}_{i}\right)}\right)+\left(1-X_{i+1}\right)\left(1-e^{\left(-k \mathrm{LAI}_{i+1}\right)}\right)}{2}\right)\left(t_{i+1}-t_{i}\right)
$$

The length of the observation period was shorter in the summer (40 days in 1997) and autumn seasons (42 days in 1999) than in the winter season (63 days in 1998). To enable a comparison among experiments, the integral variables were divided by the time $\left(t_{n}-t_{1}\right)$ over which the integration (or summation) was carried out. All standardized variables were marked with *. Thus, $\mathrm{AUDPC}_{R} *$ is the standardized area under the rust progress curve and can be interpreted as the mean daily rust severity during the whole season.

Combined analysis. To investigate the effects of both diseases on LAD* in all 36 plots of the three experiments simultaneously, the following model was used:

$$
\begin{gathered}
\mathrm{LAD}^{*}=\left(d_{1} \times \mathrm{LAD}_{1} *+d_{2} \times \mathrm{LAD}_{2} *+d_{3} \times \mathrm{LAD}_{3}^{*}\right) \times \\
\left(1-c_{R} \times \mathrm{AUDPC}_{R}{ }^{*}-c_{A} \times \mathrm{AUDPC}_{A} *-c_{A R} \times \mathrm{AUDPC}_{A} * \times \mathrm{AUDPC}_{R} *\right)
\end{gathered}
$$

In this equation, the $d_{j}$ are dummy variables ( 0 or 1$)$ to choose the year. The three parameters $\mathrm{LAD}_{j}$ * represent the level of potential duration of the leaf area index assigned to each experiment. The coefficients $c_{R}$ and $c_{A}$ describe the reduction in leaf area for the individual diseases and $c_{A R}$ for the interaction of both diseases.

Under the assumption that yield $(Y)$ is determined by the leaf area index duration (LAD*), the following equation was fitted to the data of the 36 plots:

$$
\begin{gathered}
Y=\left(a_{1}+a_{2} \times \mathrm{LAD}^{*}\right) \cdot\left(1-b_{R} \times \mathrm{AUDPC}_{R}^{*}-b_{A} \times \mathrm{AUDPC}_{A} *-b_{A R} \times\right. \\
\left.\operatorname{AUDPC}_{A} * \times \operatorname{AUDPC}_{R} *\right)
\end{gathered}
$$

where the coefficients $b_{R}$ and $b_{A}$ represent the effects of the individual diseases on yield, and the interaction term $b_{A R}$ represents the combined effect of both diseases. 
Data analysis. Analysis of variance was conducted using the SAS system (SAS Institute, Cary, NC) and statistical differences between the means of the treatments were determined with the Tukey test. Linear regression analyses, performed by the Statistica software (StatSoft, Tulsa, OK), were used to quantify the relationships among variables; for example, between yield and HAD*.

\section{RESULTS}

Disease severities, crop growth, and yield in the 1997 experiment. In this experiment, carried out in the summer, the visual angular leaf spot severity on attached leaves was higher than the rust severity (Figs. 1 to 3 ). The maximum severity value of angular leaf spot in the four treatments was nearly $4 \%$, but only $0.3 \%$ for bean rust. In all plots, natural infections of both pathogens occurred. When $P$. griseola was inoculated in combination with $U$. appendiculatus (treatment $\mathrm{P}+\mathrm{U}$ ), $\mathrm{AUDPC}_{A} *$ was not statistically different from the treatment in which $P$. griseola was inoculated alone (treatment P) (Fig. 3). The severity of rust was, in general, very low. Rust reached its highest severity in treatment U (Fig. 1). The progress curves of HLAI in treatments $\mathrm{C}$ (control) and $\mathrm{U}$ were similar (Fig. 1). The maximum values of HLAI were lower for treatments $\mathrm{P}$ and $\mathrm{P}+\mathrm{U}$ compared with treatments $\mathrm{U}$ and $\mathrm{C}$.

When virtual severity values were considered, the severity values were higher, especially for angular leaf spot (Fig. 4), but the shape of the progress curves and the relations among the treatments were not altered (Figs. 2 and 4). The values of ELAI were only slightly smaller than the corresponding HLAI values (Figs. 2 and 4).

Larger AUDPC occurred for angular leaf spot $\left(\mathrm{AUDPC}_{A} *\right.$ ) than for rust $\left(\mathrm{AUDPC}_{R}{ }^{*}\right)$ (Figs. 1 and 3 ). There were no significant differences among the treatments for AULAPC*, HAD*, and HAA* $(P>0.05)$. However, all inoculated treatments differed statistically from the control in disease severity and yield (Fig. 3).

Disease severities, crop growth, and yield in the 1998 experiment. In this experiment, carried out in the winter season with lower temperatures, the weather conditions were favorable for bean rust, which resulted in a significantly higher value for $\mathrm{AUDPC}_{R} *$ compared with $\mathrm{AUDPC}_{A} *$ (Figs. 1 and 3). Maximum visual severity of rust was $1.4 \%$ (treatment $\mathrm{U}$ ), whereas angular leaf spot reached only $0.6 \%$ even in the plots inoculated with $P$. griseola (treatments $\mathrm{P}$ and $\mathrm{P}+\mathrm{U}$ ) (Fig. 2). Rust severity reached a maximum value of $0.9 \%$ in treatment $\mathrm{P}$ by natural infections. In general, the length of the epidemics in this season was longer than in the previous experiment, but the maximum values for HLAI were lower (Fig. 2). In the inoculated treatments, a similar pattern of the dynamics of HLAI (Fig. 2) was observed.

Again, the disease progress curves changed only slightly when the virtual disease severity was analyzed (Fig. 4). The progress curves for HLAI and ELAI were nearly identical (Figs. 2 and 4).

The differences in AULAPC*, HAD*, and HAA* among all treatments (including the control) were not significant $(P>0.05)$, but the disease severity and yield of the inoculated treatments differed from the control. No significant difference in yield was obtained among the three inoculated treatments (Fig. 3).

Disease severities, crop growth, and yield in the 1999 experiment. This experiment was conducted in the autumn, with weather conditions favorable especially for angular leaf spot. Similar to the 1997 experiment, angular leaf spot severity was higher than rust severity (Figs. 1 to 3 ). For all treatments, a similar progress of HLAI was observed, but the leaf area remained at a high level for a longer time in the control treatment compared with the inoculated treatments (Fig. 2). The maximum level of HLAI in the control treatment was less than 3.5 and substantially lower than in the 1997 experiment (Fig. 2).

Values of virtual disease severities were higher than visual severities, especially for angular leaf spot (Fig. 4), but the patterns of disease progression did not change (Figs. 2 and 4). Also, the ELAI curves were similar to the HLAI curves (Figs. 2 and 4).
There were no significant differences among all treatments for AULAPC*, HAD*, and HAA* $(P>0.05)$ (Fig. 3). However, disease severities and yields were statistically different in the three inoculated treatments compared with the control (Fig. 3).

Comparison of the three experiments. The three experiments conducted in three different seasons resulted in different levels of the two diseases. When the standardized AUDPCs were considered, levels for both diseases were low in 1997, although angular leaf spot was more prevalent (Fig. 1). In 1998, bean rust predominated and reached the highest level of all three experiments. The conditions in 1999 were more favorable for angular leaf spot than for rust, which led to the highest level of angular leaf spot in all experiments (Fig. 1).

In 1997 and 1999, the conditions for the growth of bean plants were more favorable than in 1998. This can be seen in the lower values of HAD* and HAA* in the 1998 experiment. Also, the yield in the winter season in 1998 was lower than in 1997 (summer season) and in 1999 (autumn season).

Relationships between AUDPC*, HAD*, ELAD*, HAA*, and yield. The relationships between yield and the integral variables AUDPC*, HAD*, ELAD*, and HAA* for all marked plants were separately investigated in the three experiments (Fig. 5). The $\mathrm{AUDPC}_{T}{ }^{*}$ of the total visual disease was not related to yield (Fig. 5). The relationships were not improved with $\mathrm{AUDPC}_{\beta T^{*}}$ used for the virtual disease. In 1997 and 1999, yield increased with the increased HAD* $\left(R^{2}=0.57\right.$ and 0.43$)$ or ELAD* $\left(R^{2}=0.58\right.$ and $0.43)$ (Fig. 5). This positive relationship was even clearer when $\mathrm{HAD}^{*}$ or ELAD* was replaced by HAA* $\left(R^{2}=0.60\right.$ and 0.55$)$. In the 1998 experiment with low yield, the yield was not related significantly to HAD*, ELAD*, or HAA*.

When the plant data of the 3 years were combined, no significant relationship between $\mathrm{AUDPC}_{T}{ }^{*}$ and $\mathrm{AUDPC}_{\beta T} *$ existed, whereas $\mathrm{HAD}^{*}, \mathrm{ELAD}^{*}$, and $\mathrm{HAA}^{*}$ were significantly related to yield with $R^{2}$ values between 0.35 and 0.53 . However, the relation between HAA* and yield was not linear for the combined data (data not shown).

Combined analysis on a plot basis. Because the variation in all variables was quite high on a plant basis, additional analyses were carried out on a plot basis with the 36 plots in all experiments together. For this analysis, the different levels of LAD* and

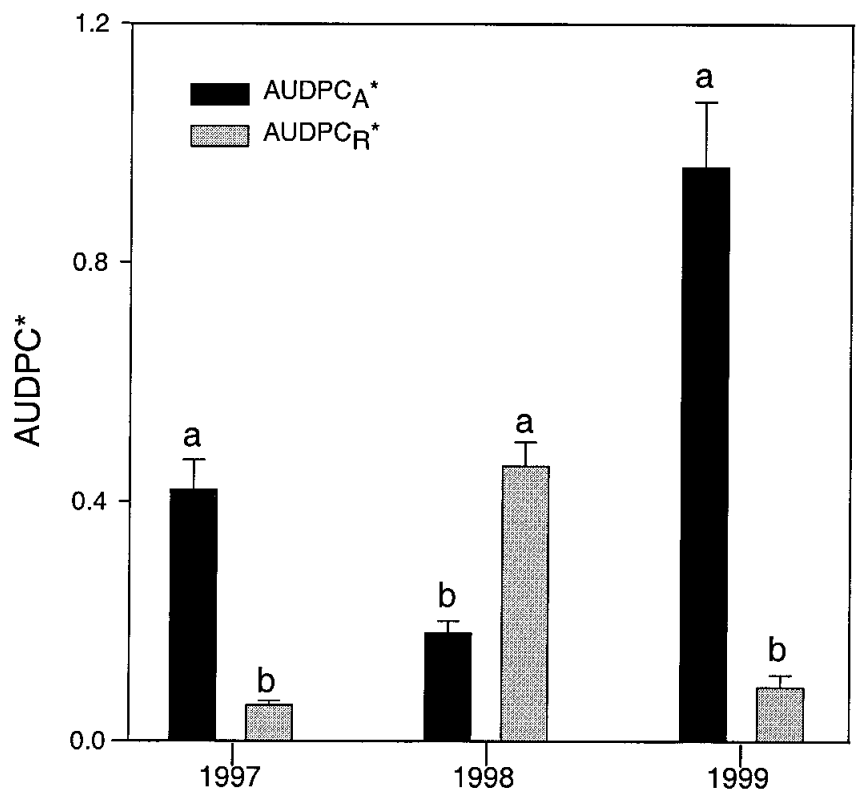

Fig. 1. Standardized areas under visual disease progress curve of angular leaf spot $\left(\mathrm{AUDPC}_{A}{ }^{*}\right)$ and of rust $\left(\mathrm{AUDPC}_{R}{ }^{*}\right)$, averaged over all treatments, from the experiments in 1997, 1998, and 1999. Vertical bars represent \pm standard error. 
HAD* in the three experiments (Fig. 3) were taken into consideration. To ascertain the effects of both diseases on the actual LAD*, equation 1 was fitted to the combined data on a plot basis. The estimated coefficient $c_{R}$ was not different from zero, which meant that bean rust had no effect on the leaf area, at least not at the low disease level observed. After the term that contained $c_{R}$ was removed from equation 1 , the equation was fitted again to the combined data, which resulted in an equation with coefficients significantly different from zero and explained $68.3 \%$ of the variation in $\mathrm{LAD}^{*}$. The estimated levels for $\mathrm{LAD}_{j}^{*}$ in the 3 years were $2.92( \pm 0.16), 1.37( \pm 0.12)$, and $2.65( \pm 0.20)$, which correlated with the different favorabilities of the seasons for bean growth. Angular leaf spot reduced LAD* $\left(c_{A}=0.28 \pm 0.075\right)$, whereas the interaction coefficient, $c_{A R}=-1.12 \pm 0.36$, led to an
1997
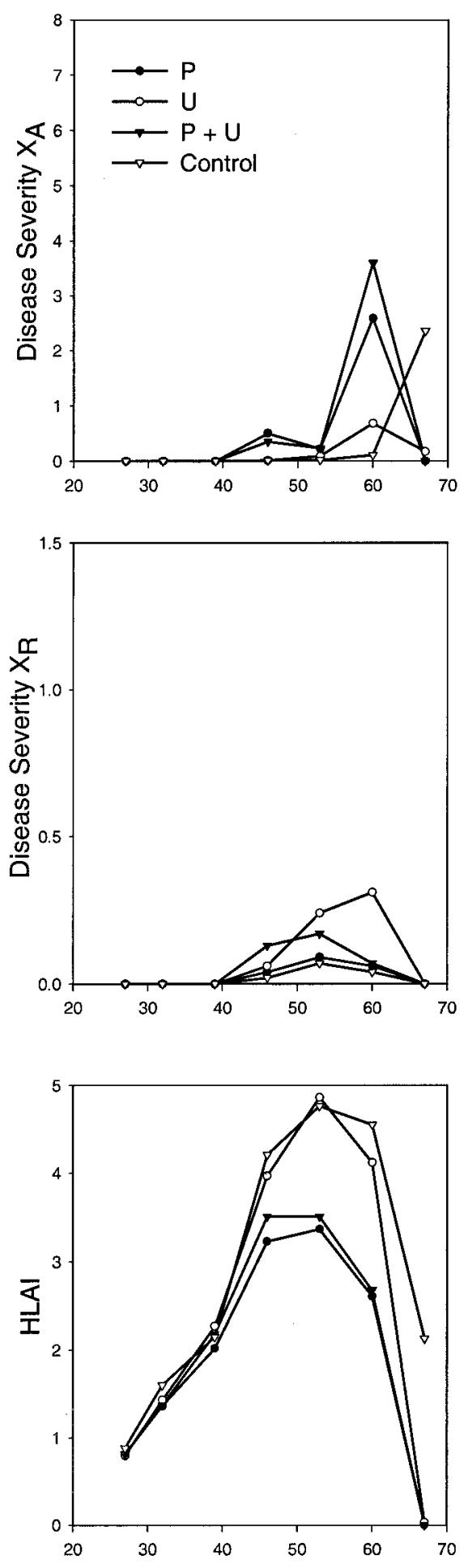

1998
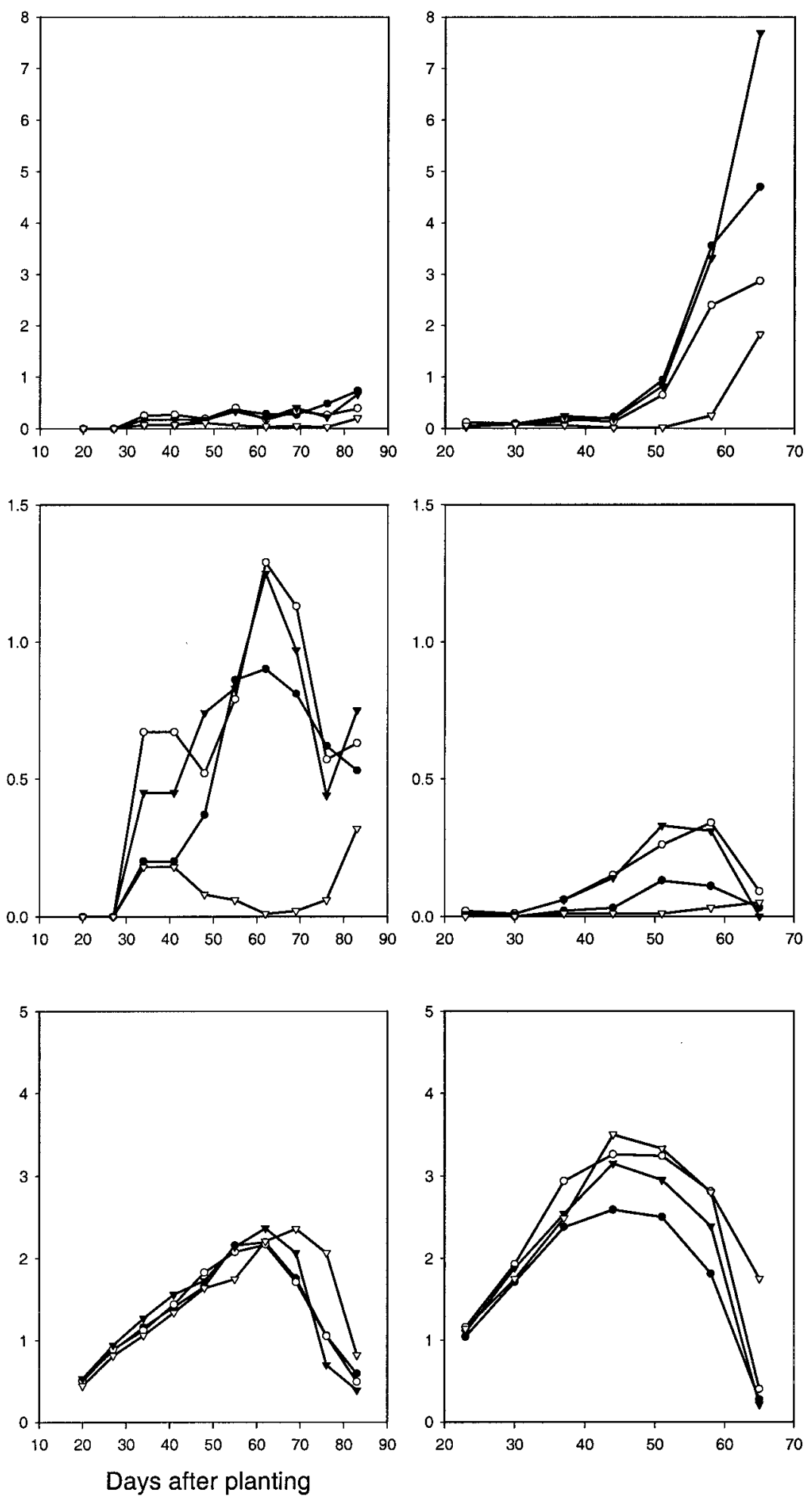
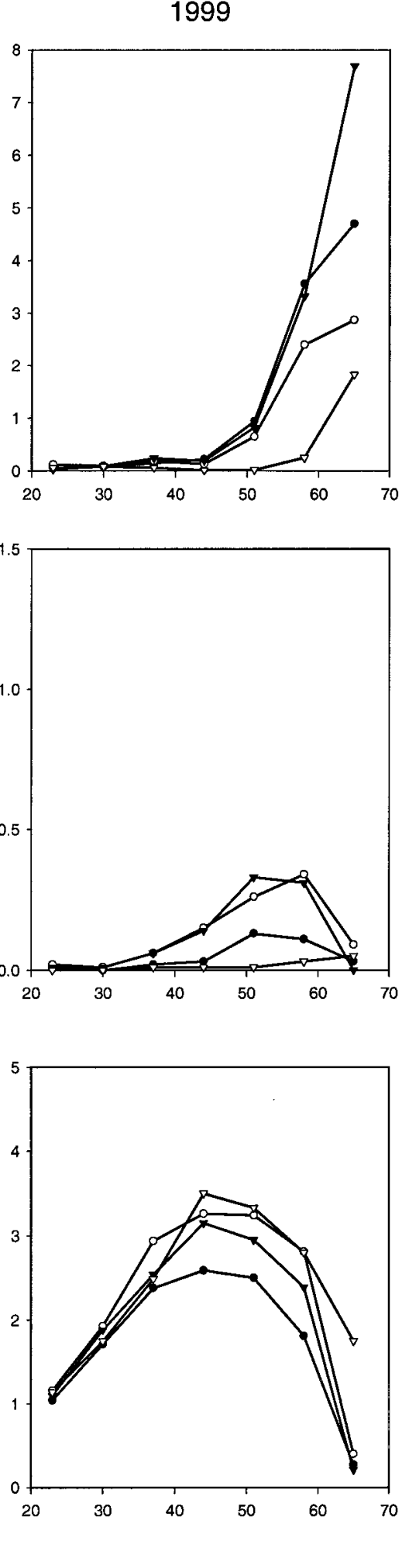

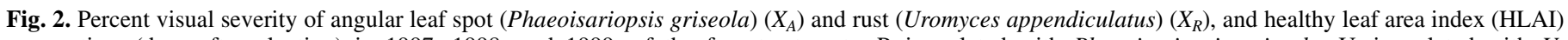

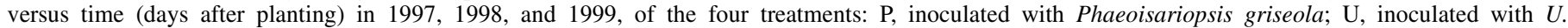
appendiculatus; $\mathrm{P}+\mathrm{U}$, inoculated with Phaeoisariopsis griseola and $U$. appendiculatus; and control, not inoculated but sprayed with tebuconazole. 
increase in LAD*. When all disease effects were removed from equation 1 , the resulting equation explained only $56.5 \%$ of the variation in LAD*. Thus, LAD* was mainly determined by the conditions of the seasons. However, angular leaf spot had a clear reducing effect on LAD*, whereas rust had no influence on the leaf area.
When model 2 was fitted to the yield data on a plot basis, the interaction term $b_{A R}$ was not significantly different from zero. After this term was removed from the equation, all estimated coefficients were significantly different from zero: $a_{1}=-98.03 \pm 37.73$, $a_{2}=130.57 \pm 16.04, b_{A}=0.1917 \pm 0.067$, and $b_{R}=0.9177 \pm$
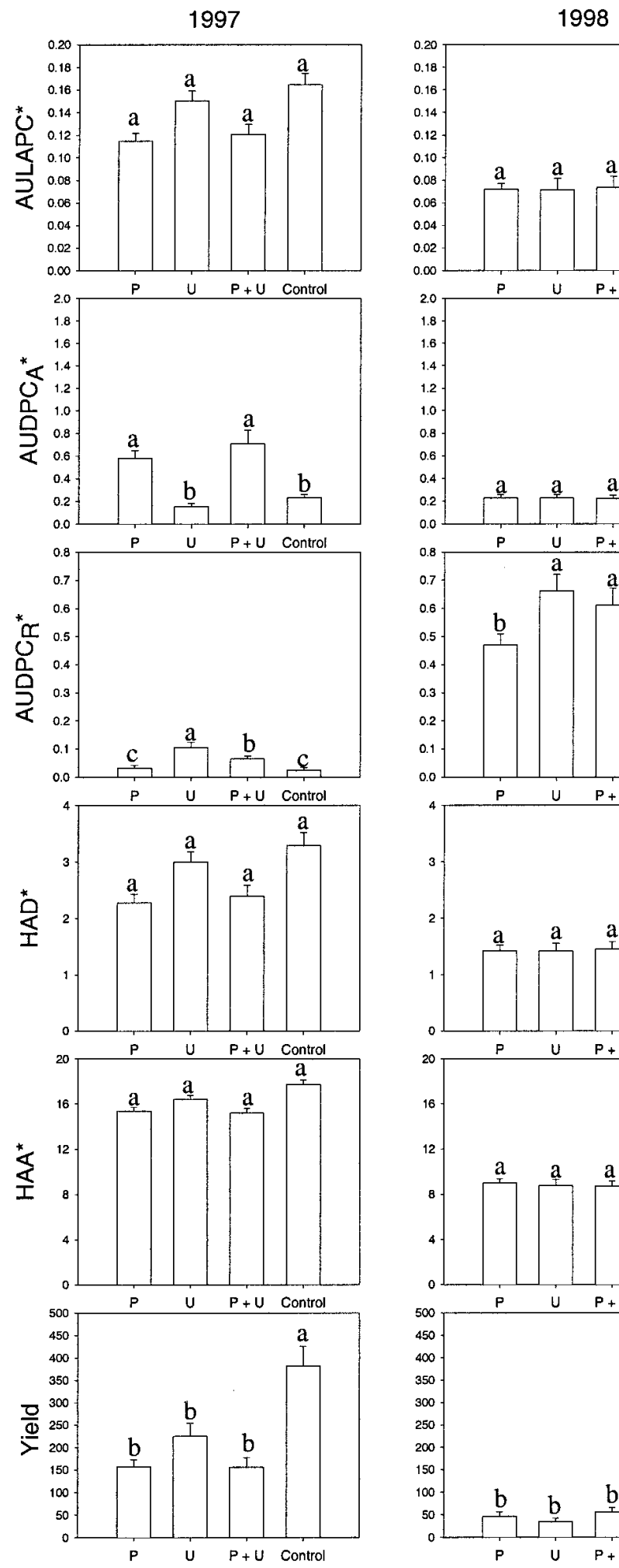

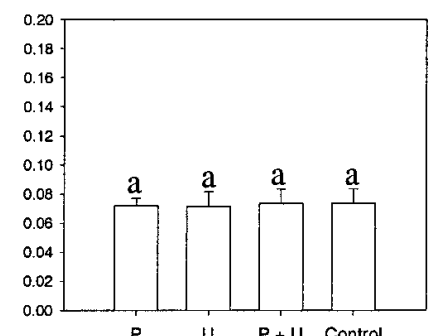

1998
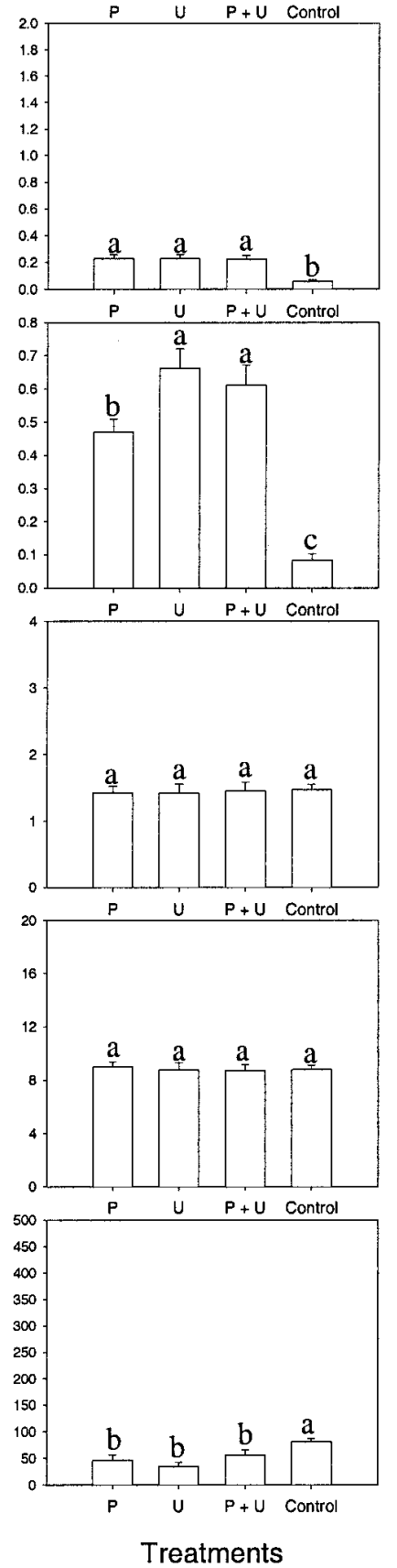
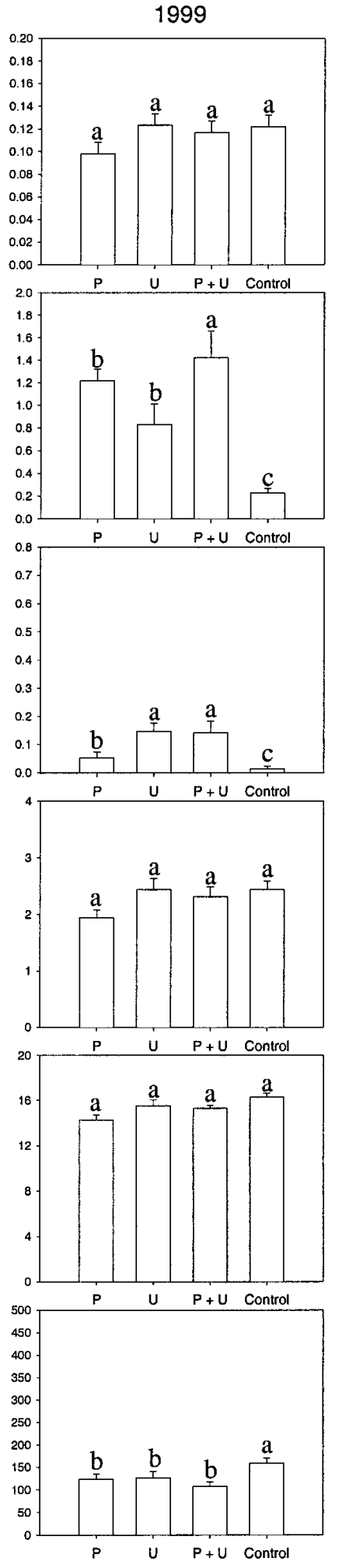

Fig. 3. Area under leaf area progress curve (AULAPC*), area under visual disease progress curve of angular leaf spot (Phaeoisariopsis griseola) (AUDPC $\left.{ }_{A}^{*}\right)$ and of rust (Uromyces appendiculatus) $\left(\mathrm{AUDPC}_{R}{ }^{*}\right)$, healthy leaf area duration (HAD*), healthy leaf area absorption (HAA*), and yield in 1997, 1998, and 1999, for the four treatments: $\mathrm{P}$, inoculated with Phaeoisariopsis griseola; $\mathrm{U}$, inoculated with $U$. appendiculatus; $\mathrm{P}+\mathrm{U}$, inoculated with Phaeoisariopsis griseola and $U$. appendiculatus; and control, not inoculated but sprayed with tebuconazole. Vertical bars represent \pm standard error, and $*$ represents standardized variable. The means for each bar followed by the same letter are not significantly different $(P<0.05)$. 
0.2598. An $\mathrm{AUDPC}_{R} *$ value of 0.2 , i.e., a mean rust severity of $0.2 \%$ over the whole season, reduced yield by approximately $18 \%$, whereas the same disease level for angular leaf spot caused losses of less than $4 \%$. This model explained $79 \%$ of the variation of yield. If yield was regressed only with LAD* and the disease terms were neglected, the estimated parameters were $a_{1}=-113.69 \pm$ 32.37 and $a_{2}=118.73 \pm 14.51$, and the explained variation in yield was only $66.31 \%$. Thus, LAD* was the most important factor for the formation of yield and this term explained $66 \%$ of the variation in yield, but the two diseases explained an additional $13 \%$ of the variation in yield.

\section{DISCUSSION}

To ascertain the effect of a disease on a crop, single-point, multiple-point, and integral models have been used to describe the relationship between disease severity and crop yield. Single-point and multiple-point models relate yield to disease severity at a
1997
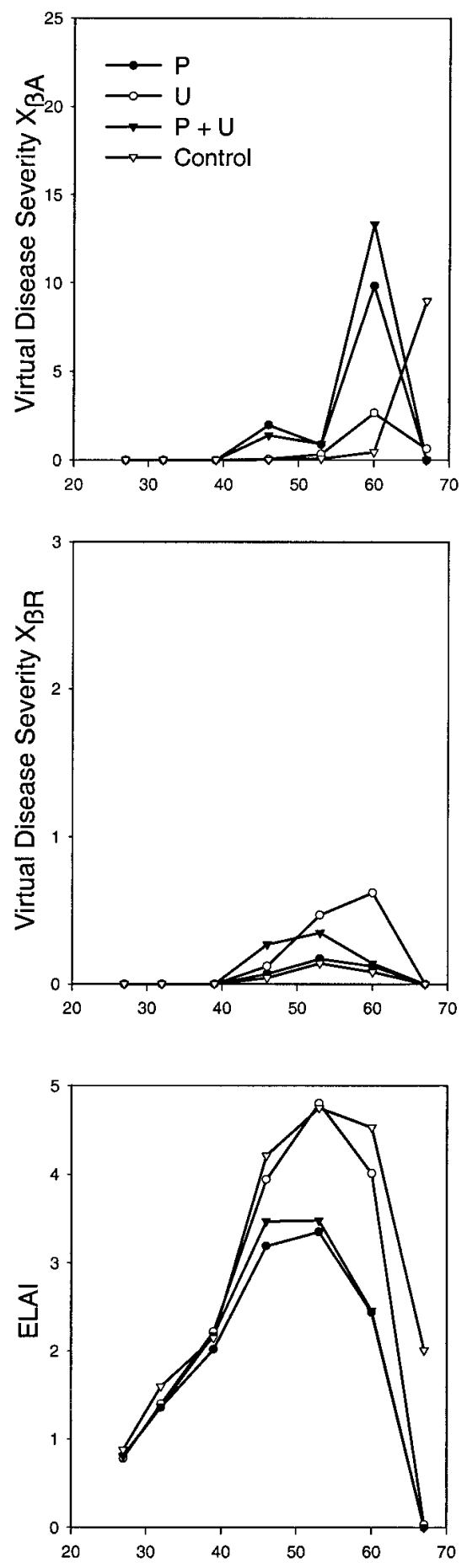

1998
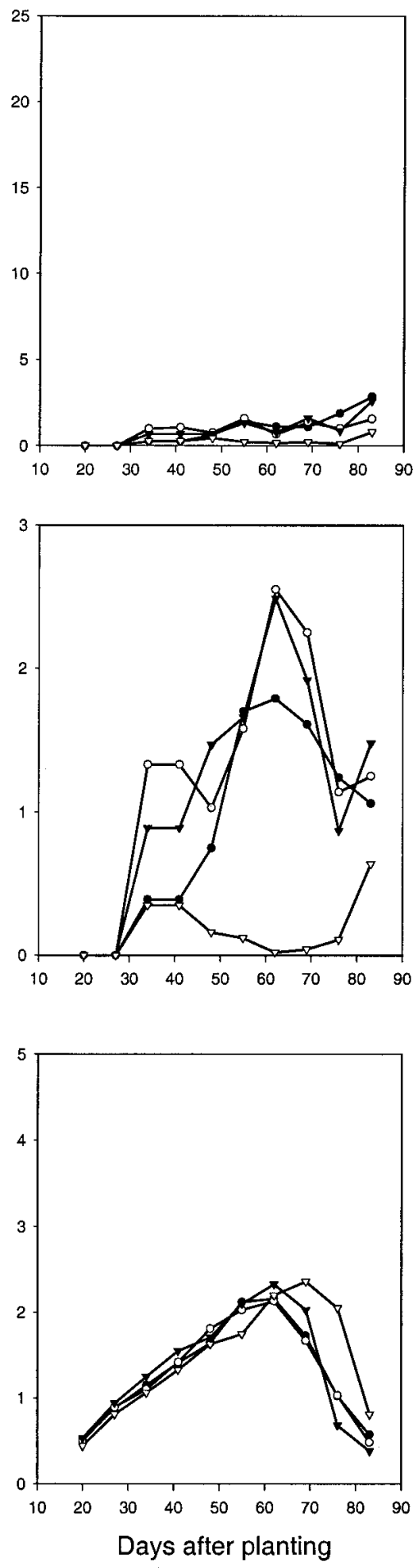

1999
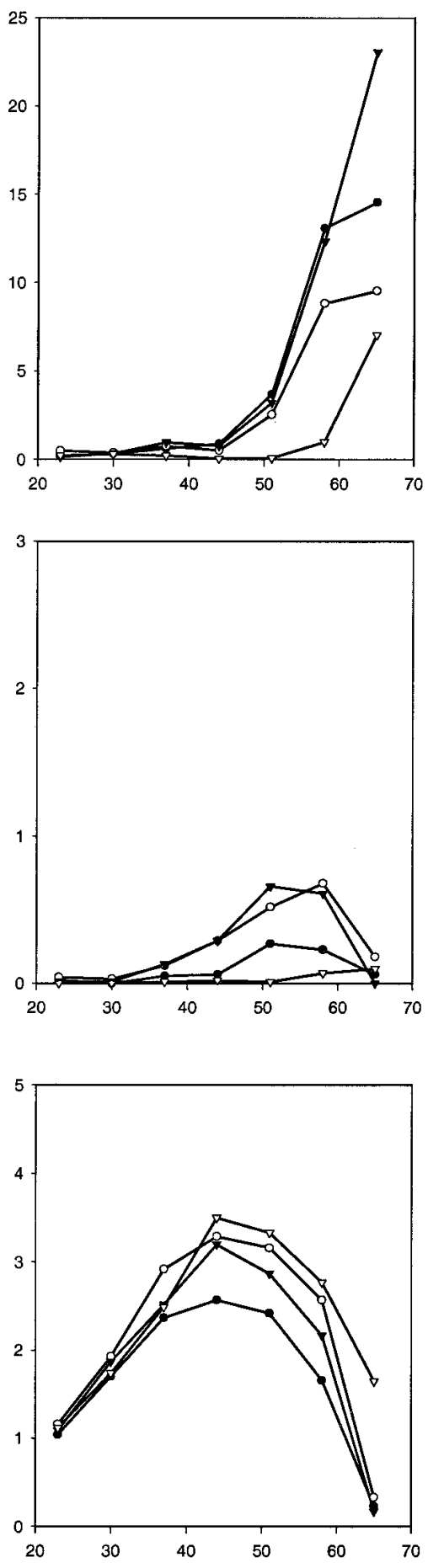

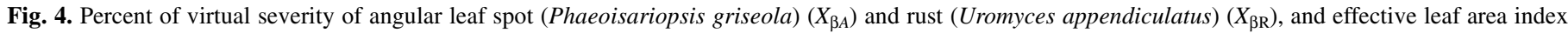

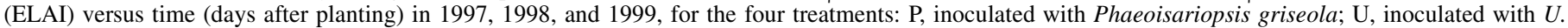
appendiculatus; $\mathrm{P}+\mathrm{U}$, inoculated with Phaeoisariopsis griseola and $U$. appendiculatus; and control, not inoculated but sprayed with tebuconazole. 
single growth stage of the crop or at several growth stages, respectively. Integral models correlate yield with the AUDPC calculated over the whole observation period. Because the duration of the three epidemics varied in our experiments, a comparison of the integral variables was only possible after the standardization of the values by dividing with the length of the observation time. For
AUDPC, this standardization resulted in the mean disease severity over the whole season. These full-season disease averages were used in this paper rather than weighing disease by host phenology. This approach was chosen because no knowledge was available about the vulnerability of bean plants to disease-induced yield loss in particular growth stages. If a critical growth stage could be
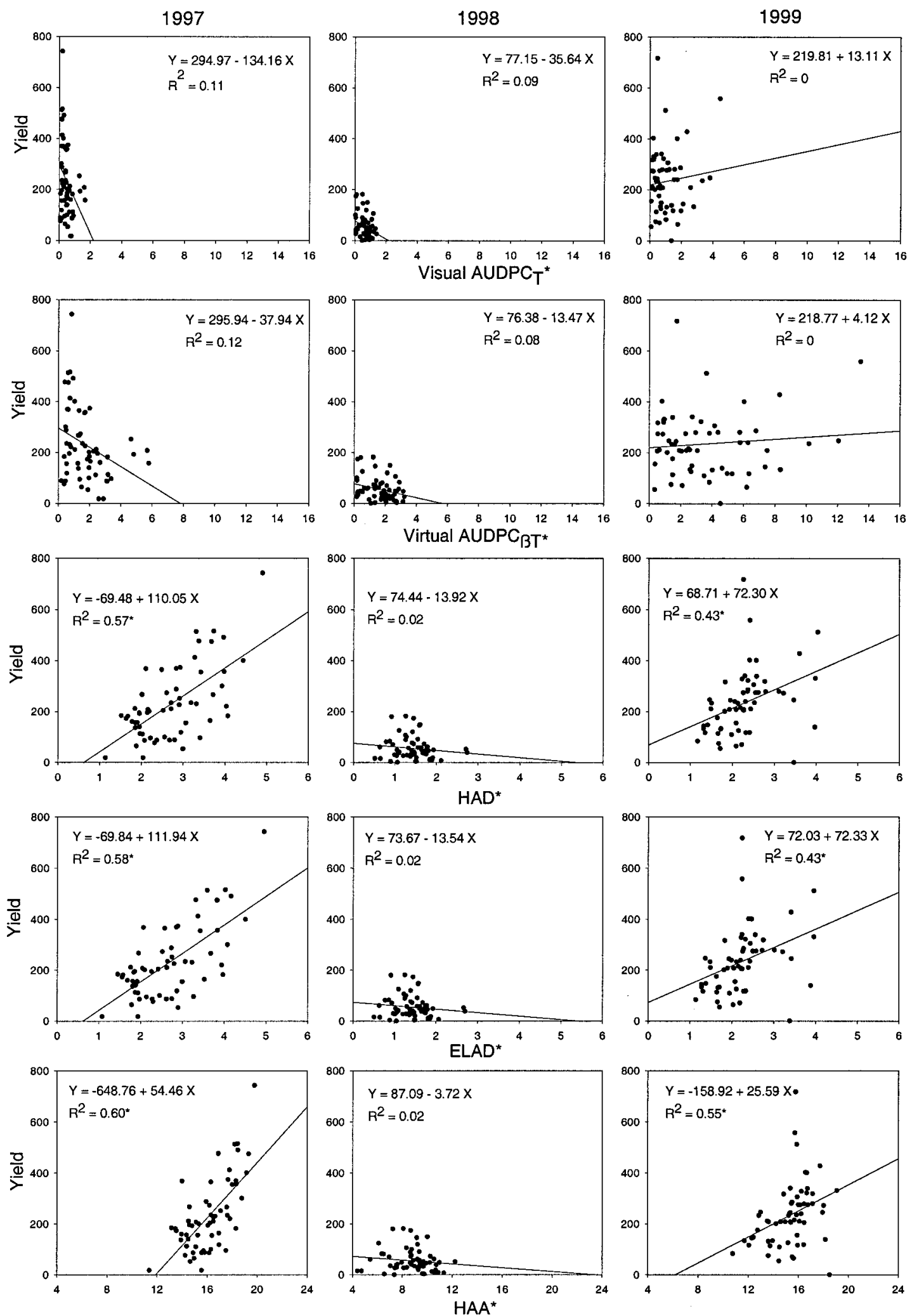

Fig. 5. Relation between yield (gram per square meter) and area under total visual disease progress curves (AUDPC $T_{T}^{*}$ ), area under total virtual disease progress curves $\left(\mathrm{AUDPC}_{\beta T^{*}}\right)$, healthy leaf area duration $\left(\mathrm{HAD}^{*}\right)$, effective leaf area duration (ELAD*), and healthy leaf area absorption (HAA*) for individual bean plants (60 plants per trial) in 1997, 1998, and 1999. All integral variables were standardized (marked with *). 
identified, a single-point model could be constructed that would overcome the problem with the standardized AUDPC values. Moreover, if the effects of growth stages over the whole season were known for both diseases, it would be possible to weigh the disease values by a function of the growth stages, which may lead to stronger relationships with yield. To deal with angular leaf spot on beans, Bergamin Filho et al. (4) developed models to predict yield dependent on the growth stages.

In the three field experiments conducted in different seasons, a significant difference between the disease levels of angular leaf spot and rust, expressed as AUDPC*, was observed. The experiments in the summer (1997) and autumn (1999) season had higher disease levels of angular leaf spot compared with rust, whereas in the winter season (1999) rust was the dominating disease. These observations agree with Coelho (9). The winter season also had a marked effect on bean growth, which is shown in the lower values for HAD* and HAA* as well as for yield in the 1998 experiment compared with the two other years (Fig. 3, control treatment). Within experiments, no significant differences among the treatments for the variables AULAPC*, HAD*, and HAA* existed, although the yield in the control plots was significantly higher in all years but significantly different from year to year. Thus, the base yield of the disease-free crop varied, which is one of the reasons why there are problems in using disease-crop-loss models in other seasons and locations (4).

In all three trials, no relationships between AUDPC* and yield were found (Fig. 5), which was also supported by other experiments $(4,5,7,17)$. Usually, the absence of a relationship between AUDPC and yield is more common when data from different seasons are compared $(12,13)$. HAD*, ELAD*, or HAA* were closely related to yield, which is in accordance with several other investigations $(4,27,29)$. Similar to our findings, in other experiments with bean diseases $(4,8,17,32), \mathrm{HAD}^{*}$ or HAA* and yield were linearly related.

Visual lesions of both diseases were assessed, but virtual lesions (3) were also considered. The relation between virtual and visual lesion, given by the parameter $\beta$, is a way to describe the decrease in leaf photosynthesis due to a disease. The $\beta$ values applied in this study were $\beta_{R}=2$ for bean rust (2) and $\beta_{A}=4$ for angular leaf spot (2). Both values were determined by the reduction of photosynthetic efficiency. The resulting ELAD* values (or PAD* sensu Bassanezi et al. [2]) were slightly more related to yield than HAD*, which is in accordance with previous results (2).

For our experiments, the single plant approach was adopted (20). Because individual marked plants were used, the variation in leaf area and yield was high among plants although the levels of diseases were rather low. On a plant basis, the natural variability in yield was higher than the effects of the diseases, a phenomenon that usually occurs in experiments with the single plant approach and low disease levels (16). To remove part of the variation, the analysis was carried out on a plot basis (five plants).

From our analyses, we found the different ways in which the two diseases reduced yield. As shown with equation 1, the effect of angular leaf spot was mainly due to defoliation that led to a reduction of the total leaf area. It is well known $(8,10,11,32)$ that angular leaf spot causes defoliation of diseased leaves. According to our analysis, the reduction in $\mathrm{LAD}^{*}$ was related to the observed disease severities of the remaining plant area. This is in contradiction to the results of Bergamin Filho et al. (4) who reported that plants with a higher severity of angular leaf spot had larger leaf areas in four out of five experiments. It can be assumed that defoliation depends on the disease severity of angular leaf spot of the affected leaves. Because defoliation was not determined in our study, this assumption cannot be validated. A second effect of angular leaf spot was detected with equation 2 . This was the reduction in leaf photosynthesis, expressed in the $\beta$ value of approximately 4.
Bean rust did not cause defoliation (insignificant coefficient $c_{R}$ in equation 1), but rust had a much stronger effect on loss in yield compared with angular leaf spot $\left(b_{R}=0.92\right.$ versus $\left.b_{A}=0.19\right)$ in equation 2. When the concept of the virtual lesion is considered, this result was rather unexpected, because both diseases reduced leaf photosynthesis, but the $\beta$ value of 4 for angular leaf spot (2) was twice the $\beta$ value of 2 assumed for rust (2). In the measurement of photosynthesis, Lopes and Berger (23) determined a $\beta$ value for rust near to 1 , which meant that the effect of this pathogen on the remaining green leaf area was minimal. In a previous study, Schuld (30) estimated $\beta_{R}$ values from the correlation between ELAD and yield, which ranged from 4 to 13 in different experiments. This was an indication that the effect of rust on yield was stronger than one would expect from the reduction in photosynthesis. The severe effect of bean rust on yield may be connected with the biotrophic nature of this pathogen. The rust pustules act as sinks for carbohydrates $(22,38)$, which then could not be allocated for production of yield.

With equation 1, no interaction of both diseases with respect to their combined effect on host growth could be shown. Contrarily, a combined effect of both diseases on yield was proven by the significant interaction term in equation 2 . There seems to be an antagonistic effect of the diseases because the sign of the interaction coefficient was negative.

Further research on yield loss caused by disease complexes is needed. Disease components must be studied separately from any interaction with other diseases, insects, weeds, and unusual physical conditions. Once a baseline for potential yield loss is determined for each pathogen, the effect of two or more pathogens on a host can be determined under different environmental conditions. In the future, such research will provide realistic information for the grower to decide what control measures to apply.

\section{ACKNOWLEDGMENTS}

This research was partially supported by the European Commission (project ERBIC18CT96-0037), FAPEMIG, and FINEP. W. C. Jesus Junior was supported by CAPES. We thank R. D. Berger (University of Florida) for reviewing this manuscript and providing suggestions for its improvement.

\section{LITERATURE CITED}

1. Bassanezi, R. B., Amorim, L., Bergamin Filho, A., and Hau, B. 1998. Effects of bean line pattern mosaic virus on the monocyclic components of rust and angular leaf spot of Phaseolus bean at different temperatures. Plant Pathol. 47:289-298.

2. Bassanezi, R. B., Amorim, L., Bergamin Filho, A., Hau, B., and Berger, R. D. 2001. Accounting for photosynthetic efficiency of bean leaves with rust, angular leaf spot and anthracnose to assess crop damage. Plant Pathol. 50:1-11.

3. Bastiaans, L. 1991. Ratio between virtual and visual lesion size as a measure to describe reduction in leaf photosynthesis of rice due to leaf blast. Phytopathology 81:611-615.

4. Bergamin Filho, A., Carneiro, S. M. T. P. G., Godoy, C. V., Amorim, L., Berger, R. D., and Hau, B. 1997. Angular leaf spot of Phaseolus beans: Relationships between disease, healthy leaf area, and yield. Phytopathology 87:506-515.

5. Bissonnette, S. M., D’Arcy, C. J., and Pedersen, W. L. 1994. Yield loss in two spring oat cultivars due to Puccinia coronata $\mathrm{f}$. sp. avenae in the presence or absence of barley yellow dwarf virus. Phytopathology 84:363-371.

6. Brenes, B. M., Chaves, G. M., and Zambolim, L. 1983. Estimativas de perdas no rendimento do feijoeiro comum (Phaseolus vulgaris) causadas pela mancha angular (Isariopsis griseola Sacc.). Fitopatol. Bras. 8:599.

7. Bryson, R. J., Sylvester-Bradley, R., Scott, R. K., and Paveley, N. D. 1995. Reconciling the effects of yellow rust on yield of winter wheat through measurements of green leaf area and radiation interception. Pages 9-18 in: Physiological Responses of Plants to Pathogens. R. D. Walters, J. D. Scholes, R. J. Bryson, N. D. Paul, and N. McRoberts, eds. Association of Applied Biologists, Wellesbourne, Warwick, England.

8. Carneiro, S. M. T. P. G., Amorim, L., and Bergamin Filho, A. 1997. Avaliação de dano provocado pela mancha angular em feijoeiro: Relação 
entre severidade, área foliar e componentes de produção. Fitopatol. Bras. 22:427-431.

9. Coelho, R. R. 1999. Caracterização das condições climáticas que favorecem o desenvolvimento da mancha angular e ferrugem do feijoeiro. M.S. thesis. Universidade Federal de Viçosa, MG, Brazil.

10. do Vale, F. X. R., Costa, H., and Zambolim, L. 1997. Feijão comum. Controle de doenças. Doenças da parte aérea causadas por fungos. Pages 335-373 in: Controle de Doenças de Plantas. Grandes Culturas. Vol. 1. F. X. R. do Vale and L. Zambolim, eds. Ministério da Agricultura e do Abastecimento, Brazil.

11. Ferraz, S. 1980. La mancha foliar angular. Pages 55-64 in: Problemas de Producción del Fríjol: Enfermedades, Insectos, Limitaciones Edáficas e Climáticas de Phaseolus vulgaris. H. P. Schwartz and G. E. Gálvez, eds. CIAT, Cali, Colombia.

12. Gaunt, R. E. 1995. The relationship between plant disease severity and yield. Annu. Rev. Phytopathol. 33:119-144.

13. Gaunt, R. E., and Bryson, R. J. 1995. Plant and crop yield potential and response to disease. Pages 1-7 in: Physiological Responses of Plants to Pathogens. R. D. Walters, J. D. Scholes, R. J. Bryson, N. D. Paul, and N. McRoberts, eds. Association of Applied Biologists, Wellesbourne, Warwick, England.

14. Godoy, C. V., Carneiro, S. M. T. P. G., Iamauti, M. T., Dalla Pria, M., Amorim, L., Berger, R. D., and Bergamin Filho, A. 1997. Diagrammatic scales for bean diseases: Development and validation. Z. Pflanzenkr. Pflanzenschutz 104:336-345.

15. Gregory, P. H. 1948. The multiple-infection transformation. Ann. Appl. Biol. 35:412-417.

16. Hamelink, J., Hau, B., and Kranz, J. 1988. Untersuchungen zur Entwicklung von Befalls/Verlust-Relationen bei Schaderreger-Komplexen an Einzelpflanzen des Maises. Z. Pflanzenkr. Pflanzenschutz 95:258-269.

17. Iamauti, M. T. 1995. Avaliação dos danos causados por Uromyces appendiculatus no feijoeiro. Ph.D. diss. Escola Superior de Agricultura Luiz de Queiroz, Piracicaba, SP, Brazil.

18. Johnson, K. B. 1990. Assessing multiple pest population and their effects on crop yield. Pages 203-213 in: Crop Loss Assessment in Rice. P. S. Teng, ed. International Rice Research Institute, Manila, Philippines.

19. Johnson, K. B., Teng, P. S., and Radcliffe, E. B. 1987. Analysis of potato foliage losses caused by interacting infestations of early blight, Verticillium wilt, and potato leafhopper, and the relationship to yield. Z. Pflanzenkr. Pflanzenschutz 94:22-23.

20. Kranz, J., and Jörg, E. 1989. The synecological approach in plant disease epidemiology. Rev. Trop. Plant Pathol. 6:27-38.

21. Latch, G. C. M., and Potter, L. R. 1977. Interaction between crown rust (Puccinia coronata) and two viruses of ryegrass. Ann. Appl. Biol. 87:139-145.

22. Livne, A., and Daly, J. M. 1966. Translocation in healthy and rust affected beans. Phytopathology 56:170-175.

23. Lopes, D. B., and Berger, R. D. 2001. The effects of rust and anthracnose on the photosynthetic competence of diseased bean leaves. Phytopathology 91:212-220.
24. Miglioranza, E. 1992. Modelo matemático-fisiológico para simular o crescimento e a produtividade da cultura do feijão (Phaseolus vulgaris). Ph.D. diss. Universidade Federal de Viçosa, MG, Brazil.

25. Nasser, L. C. B. 1976. Efeito da ferrugem em diferentes estádios de desenvolvimento do feijoeiro e dispersão de esporos de Uromyces phaseoli var. typica Arth. M.S. thesis. Universidade Federal de Viçosa, MG, Brazil.

26. Pinnschmidt, H. 1991. Effects of multiple pests on crop growth and yield. Philipp. Phytopathol. 27:1-11.

27. Pinnschmidt, H., Teng, P. S., and Young, L. 1994. Methodology for quantifying rice yield effects of blast. Pages 381-408 in: Rice Blast Disease. R. S. Zeigler, S. A. Leong, and P. S. Teng, eds. CAB International, Wallingford, U.K.

28. Savary, S., and Zadoks, J. C. 1991. Méthodes pour l'étude du domage dû à un ensemble de contraintes phytosanitaires. Le cas de l'arachide en Côte d'Ivoire. Pages 256-280 in: Approaches de la Pathologie des Cultures Tropicales. Example de 1'Arachide en Afrique de l'Ouest. S. Savary, ed. Ėditions de l'Orstom, Paris, France.

29. Savary, S., and Zadoks, J. C. 1992. Analysis of crop loss in the multiple pathosystem groundnut-rust-late leaf spot. I. Six experiments. Crop Prot. 11:99-109.

30. Schuld, P. 1996. Auswirkungen des Befalls durch drei Blattpathogene (Uromyces appendiculatus, Phaeoisariopsis griseola und Colletotrichum lindemuthianum) auf das Wachstum und den Ertrag von PhaseolusBohnen. Ph.D. thesis. Universität Hannover, Germany.

31. Schwartz, H. F., Correa, V. F., Pineda, D. P. A., Otoya, M. M., and Katherman, M. J. 1981. Dry bean yield losses caused by Ascochyta, angular, and white leaf spots in Colombia. Plant Dis. 65:494-496.

32. Silva, M. B., do Vale, F. X. R., Zambolim, L., and Hau, B. 1998. Efeitos da ferrugem, da antracnose e da mancha angular na área foliar de plantas de feijoeiro em condições de campo. Fitopatol. Bras. 23:442-447.

33. Van Schoonhoven, A., and Pastor-Corrales, M. A. 1987. Sistema Estándar para la evaluación de germoplasma de frijol. CIAT, Cali, Colombia.

34. Vargas, E. 1980. La roya. Pages 17-36 in: Problemas de Producción del Fríjol: Enfermedades, Insectos, Limitaciones Edáficas e Climáticas de Phaseolus vulgaris. H. P. Schwartz and G. E. Gálvez, eds. CIAT, Cali, Colombia.

35. Waibel, H. 1990. Requirements for an economic interpretation of crop losses. Pages 313-320 in: Crop Loss Assessment in Rice. P. S. Teng, ed. International Rice Research Institute, Manila, Philippines.

36. Waller, J. M., and Bridge, J. 1984. Effects of pathogen interactions on tropical crop production. Pages 311-320 in: Plant Diseases: Infection, Damage and Loss. R. H. S. Wood and G. J. Jellis, eds. Blackwell Scientific Publications, Oxford, London.

37. Weber, G. E., Gülec, S., and Kranz, J. 1994. Interactions between Erysiphe graminis and Septoria nodorum on wheat. Plant Pathol. 45:158-163.

38. Zaki, A. I., and Durbin, R. D. 1965. The effect of bean rust on the translocation of photosynthetic products from diseased leaves. Phytopathology 55:528-529. 